\title{
The Effect of Field Trips to Historical Cultural Heritage Sites on Teacher Candidates' Academic Knowledge and Their Sensitivity
}

\author{
Tulay Ocal \\ Faculty of Education, Social Studies Education, Nigde University, Nigde, Turkey \\ Email: tocal@nigde.edu.tr
}

Received 20 January 2016; accepted 24 February 2016; published 29 February 2016

Copyright (C) 2016 by author and Scientific Research Publishing Inc. This work is licensed under the Creative Commons Attribution International License (CC BY). http://creativecommons.org/licenses/by/4.0/

(c) ()

\section{Abstract}

Culture is historical cultural accumulations that are acquired rather than being born with and are bequeathed to future generations. Today, technological developments resulting from globalization have affected societies and begun to destroy cultures. Realizing this, Turkey and many countries have started Historical Cultural Heritage Education to protect historical cultural heritage and to raise awareness of younger generations. To increase the teacher candidates' academic knowledge and teach the importance of historical cultural heritage, in-class activities are done and lectures are given in universities' education faculties. However, it is seen that these activities do not make sense for them and therefore their academic knowledge and their sensitivity do not increase enough. In this study, teacher candidates' sensitivity about historical cultural heritage and their academic knowledge was determined by the field trip taken to Tarsus's historical cultural sites. The sample of this study is $\mathbf{3 0}$ second and third year social studies teacher candidates attending Niğde University. One group pre-test, post-test experimental design was used. After literature review, a 30-question survey was developed for data collection. The survey was conducted before and after the trip. The data was analyzed with SPSS. As a result of t-test, the difference between the sensitivity pre-test and post-test scores was 1.60 , which was statistically significant. The difference between the academic knowledge pre-test and post-test scores was 4.2 , which was also statistically significant. These findings showed that field trips should be organized more.

\section{Keywords}

Historical Cultural Heritage, Applied Education in Protected Historical Sites, Awareness in Education 


\section{Introduction}

People have settled in areas that were suitable for living and created cultures and carried these cultures with them to wherever they moved. With time these cultures have diversified and cultural values unique to each society have arisen. After Industrial Revolution, while the world has developed in many ways, creating a single society was forefront. Today, however, technological advances resulting from globalization have affected all societies and started to destroy multiculturalism. In addition, countries technological advancements in their hands have gathered all the other countries under one cultural umbrella. Yet, some countries in Europe that have been working to keep historical cultural heritage alive are considered to be the oldest and most important creators of historical cultural heritage. There are international organizations and agreements to protect these cultural assets or cultural heritage universally in accordance with the common principles (Emekli, 2005: p. 102). In 1972, UNESCO took important measures to protect cultural heritage with its 1972 World Heritage Convention because each society has unique cultural and historical values (UNESCO, 1972). This is important in the survival of societies and bequeathing this heritage to the future generations. Education is important in protecting this historical and cultural values and bequeathing these values to the future generations and teachers have responsibilities in this education.

Culture is historical cultural accumulations that are acquired rather than being born with and are bequeathed to future generations. Culture is everything that people have created against the nature to keep on living with the nature (Güvenç, 1994). Combining culture with geography, cultural geography puts forth spatial diversity that arises from cultural groups and society's spatial functioanlity with a geographical approach (Emekli, 2006). One of the fundamental factors bringing together nations is physical and spiritual values that people define as culture (Alım, 2009). The scientists who define culture as physical and spiritual values, also, claim that culture is knowledge accumulation in societies (Uygur \& Baykan, 2007). Culture is a common subject that is addressed by social anthropology, social psychology, history, sociology and ethnology. Of courses, each of these fields addresses culture from their perspectives (Arslanoğlu, 2001). In this way, culture is discussed and defined by social sciences that choose it as a study area (Gülcan, 2010). Geography addresses culture as processes (people’s thoughts and living styles) and products that are formed as a result of these processes (buildings, hand crafts, art and traditions) (Aliağaoğlu, 2004). Developed by geography, these cultures create both the historical cultural heritages and the tangible and intangible cultural heritages in their existing environments by shaping and combining together with time. In September 11, 1999, European Council launched a campaign called "Europe, A Common Heritage” in Bucharest. Raising cultural, natural and historical heritage awareness in Europe, improving cooperation between countries in the framework of respect for cultural diversity and bringing moral, religious and cultural values to forefront are among the campaign's purposes. Other world organizations, companies, associations and voluntary organizations support this campaign (http://www.unesco.org.tr). The decisions UNESCO took for historical and cultural heritages in 1972 and 1999 have prepared the formation of historical and cultural heritage education needed for the education of these heritages because today's technology popularized the single society and single culture understanding and therefore decreased younger generation's interest in historical cultural heritages.

Cultural are irreplaceable and non-renewable; they must be managed very carefully. These assets make it possible to make connections among the past, present and future (Tören et al., 2003; Timothy \& Boyd, 2003). Historical and cultural heritage that provides these connections must be protected. To entrust our future to them, younger generation's academic knowledge must be increased and their sensitivity towards culture must also be increased. Cultural remains such as archeological sites, monuments, mounds, tumuli, mosques and churches are remains that make up the cultural heritage and these assets are identified as places to be protected by law (Doğaner, 2003). Even though there are sanctions in the law, it is more important for these cultural works to be protected voluntarily by conscious people. It is the responsibility of our teachers to raise awareness of historical cultural heritage. Therefore, great responsibilities fall to the teaching staff at the education faculties who prepare the future teachers. However, historical and cultural heritage education in education faculties is limited by inclass activities. These techniques related to historical cultural heritage education can be found in scientific studies from different countries. There are differences in cultural heritage education among countries. In many studies, different subject teachers' academic knowledge of historical cultural heritage was determined. In a study conducted in Spain, a survey related to cultural heritage and cultural heritage education was filled out by elementary and middle school teachers. These are the results of this study: especially the history and geography teachers' responses show that their academic knowledge about historical cultural heritage was high. However, 
academic knowledge of the physics and chemistry teachers were lower than the history and geography teachers. In addition, academic knowledge of the biology geology and elementary school teachers was even lower than that of the physics and chemistry teachers. In the study, this is explained by the courses the history and geography teachers received during their university degrees related to historical cultural heritage (Giménez et al., 2008).

These differences among teachers in Spain are also seen in other European countries and there are different educational methods used in cultural heritage education. Although different educational techniques are being used today, traditional methods in cultural heritage education were used for a long time in the past. Traditional methods were used inside the classroom face to face with the teacher. In time, people's interest began to shift towards museum since these historical cultural assets were collected in the museums and people began to visit these museums to see these assets. Museum education motives people to learn as a result of meaningful experiences combining thoughts and feelings and raises people's visual awareness towards the world that encompasses them (Sternberg, 1989). From the mid-19 $9^{\text {th }}$ century, "educational museums" were founded (HooperGreenhill, 1994). The first educational museum, Haslemere Museum, was opened in England in 1894 (San, 1998). Art education through museums emerged in the West in the $19^{\text {th }}$ century. European museums became centers that collected information about the local area, protected the environment and conducted all kinds of social and cultural studies (Atasoy, 1978). The first children's museums were founded in the US and they have long history (Hooper-Greenhill, 1994; Şahan, 2005).

Museums are non-profit places with universality and continuity that collect, protect and exhibit all kinds of products in human life, builds a bridge between the past and the future, provide enjoyment for people with its informative and research opportunities, support learning and creativity (Mercin, 2002). In Turkey and in many other countries, museums have sustainability policies. While in some countries museums are independent in every way, in other countries, including Turkey, they operate under a certain ministry (Taş \& Yıldız, 2015). For example, in England museums and historical sites used many new techniques to promote themselves. Exhibitions and displays are increasing in museums due to computer programs that generate sound and light. Protected historical sites use actors in historical costumes to promote the sites (Corbishley, 2000; Güleç \& Alkış, 2003).

In the development of cultural heritage education, computer technologies are prepared as projects in European countries and are used an efficient model in education. Thus, they contribute to the knowledge accumulation. In fact, in recent years historical cultural heritage has been archived in electronically in all the developed European countries. In European countries, museums, archives, libraries and other cultural heritage are converted into digital collections. These digital resources are used for educational purposes and specifically teachers use them in historical cultural heritage activities for educational purposes (Ott \& Pozzi, 2011). In Turkey, creating this kind of digitalized museums and libraries are underway but it is not sufficient. Historical cultural heritage courses are taught as elective courses in schools that prepare teachers. Courses about historical cultural heritage in Social Studies Education departments of education faculties have been drawing interest. However, teaching is done using traditional methods or using computer technologies in class. There is a big difference between courses taught in a traditional way and taught using computer technologies. Students are more interested in courses used with computer technologies. An Italian study named "Towards a new era for cultural heritage education: Discussing the role of ICT" show that the use of information and communication technologies in historical and cultural heritage education increased students' sensitivity. In another article titled "ICT and cultural heritage education: Which added value?" same authors suggest that using computer technologies in cultural heritage education activities makes history more understandable and shapes the future better. Educational technologies have an important place in cultural heritage education. The use of information and communication techniques can be considered as a new approach and method in education (Ott \& Pozzi, 2008). Especially the museums that have digital archives and works are the places where historical cultural heritage is protected and bequeathed to the future generations and where continuity is ensured. People should live in an environment that show the historical cultural past's displays for them to have historical cultural awareness and for them to acquire cultural continuity (Alkış \& Oğuzoğlu, 2005). People should at least get information about the works displayed in the museums where this historical cultural heritage is protected and bequeathed to future generations by visiting them. According to Şahan (2005), with museum visits students get the opportunity to work actively with tangible evidence by encountering alternative learning ways. For some students this means finding the opportunity to discover their own abilities and skills that cannot be discovered in a traditional classroom setting. Museums are places where historical and cultural elements are kept alive. Even people's beliefs, life styles and psychological conditions can be understood and cultural transmission is provided. In museums culture is a transition process 
from local to national and from national to universal. In this way, there is an opportunity to transmit past societies’ cultures to the present and the future (Meydan \& Akkuş, 2014). Visiting these museums increases students’ academic knowledge about historical cultural heritage and their sensitivity towards it.

In a qualitative study titled "Examination of student perceptions of sensitivity towards cultural heritage value present in the Social Studies curriculum" one student made the following comments: "Sensitivity towards cultural heritage is like books because if we are not sensitive towards cultural heritage, we will get damaged just like books. If a book is damaged, we cannot teach the future generations. If we are not sensitive towards cultural heritage, it will get damaged just like letters” (Kilcan \& Akbaba, 2013). For students to acquire this sensitivity, students' interest and academic knowledge should be increased first. For this reason, the importance of museums and historical cultural heritage sites should be increased in addition to practical education. The value of museums in historical cultural heritage should be appreciated and given importance. Increasing the future generations' academic knowledge and sensitivity in this should be planned. However, the works conducted in museums and protected historical sites are inexpedient in Turkey and are not given importance. Also, unlike world museums, the museums in Turkey are far away from being an interactive and participatory cultural center (Tarih Vakfi, 2000). Just like how museums are organized for educational activities and presented to students' and teachers' use, the protected historical sites must also be organized and presented for community service and brought to a level where educational institutions can benefit from. Stradling (2003) express that during the field trips taken to historical and cultural sites students can walk around in historical cultural heritage sites such as old historical buildings, palaces, mosque complexes, old religious schools, churches, castles and museums. During these field trips, students recognize historical cultural assets that have damaged. During field trips and local historical and cultural project works, students can meet many specialists or amateurs working on the classification, protection, maintenance and exhibition of historical and cultural assets. This makes students realize that historical cultural heritage is not just an abstract school course and that there are many practical areas outside the classroom (Işık, 2008; Aktın, karakuş. \& Sağlam; 2013). So, with trips historical cultural heritage learning process will go beyond the textbooks and schools as sensitivity towards historical cultural heritage. The field trips as a teaching method increase the sensitivity for the past, responsibility towards historical cultural heritage and academic knowledge.

The studies about historical cultural heritage have increased in the World and naturally in Turkey. This study determined the academic knowledge about historical cultural heritage and sensitivity towards it of Social Studies teacher candidates attending Niğde University's Education Faculty through a field trip the candidates took to the historical cultural protected sites of city of Tarsus.

This template, created in MS Word 2007, provides authors with most of the formatting specifications needed for preparing electronic versions of their papers. All standard paper components have been specified for three reasons: 1) ease of use when formatting individual papers, 2) automatic compliance to electronic requirements that facilitate the concurrent or later production of electronic products, and 3) conformity of style throughout a journal paper. Margins, column widths, line spacing, and type styles are built-in; examples of the type styles are provided throughout this document and are identified in italic type, within parentheses, following the example. Some components, such as multi-leveled equations, graphics, and tables are not prescribed, although the various table text styles are provided. The formatter will need to create these components, incorporating the applicable criteria that follow.

\section{Study Purpose}

The purpose of this study is to determine the academic knowledge about historical cultural heritage and sensitivity towards it of Social Studies teacher candidates attending Niğde University’s Education Faculty through a field trip the candidates took to the historical cultural protected sites of city of Tarsus. For this reason, the following sub-questions were identified:

1) What kind of difference was there between teacher candidates' sensitivity towards historical cultural heritage after traditional lecture given to them in class and after the field trip they took to Tarsus's historical cultural heritage sites?

2) Was there a significant difference between the teacher candidates' academic knowledge before and after the field trip they took. 


\section{Limitations}

This study is limited by 30 social studies teacher candidates studying at Social Studies Education Department of Niğde University's Faculty of Education who have taken "World Cultural Regions and Tourism" course as an elective. The study is also limited by the city of tarsus's historical cultural heritage sites.

\section{Study Method}

For the design of this study one group pre-test, post-test no control group experimental design was used. "It is a research area that produces data in order to determine the cause-and-effect relationship between the variables that are under the control of the researcher” (Karasar, 2005). To examine Social Studies teacher candidates' academic knowledge and sensitivity, a 30-question scale was developed by the researcher after examining Dinç, Erdil and Sağlam's (2012), Erhan and Metin's (2012) and Aktın, Karakuş and Sağlam's (2013) studies on determining teacher candidates' interest and awareness levels. After the questions were developed, the questions were presented to scientific, linguistic and measurement and evaluation experts to test the question's validity and reliability. The questions were found reliable and valid. The seven questions were personal information about the teacher candidates; ten questions were about their sensitivity towards historical and cultural assets; 13 questions were about their academic knowledge.

\subsection{Study Universe and Sample}

The universe of the study is made up of all the teacher candidates studying at Social Studies Education Department of Niğde University's Faculty of Education. To achieve the study's purpose, purposeful sampling technique, one of the non-probability sampling techniques, was employed in order to select the participants. In purposeful sampling researchers choose the sample using their judgment to serve the purpose of the study (Monnette, Sullivan \& Dejong, 1990; Özen \& Gül, 2007; cited in: Karakuş \& Sağlam, 2013). To determine social studies teacher candidates' academic knowledge about and sensitivity levels towards Tarsus's historical cultural heritage, second-year and third-year students who live around the city of tarsus were chosen for the study. The sample of the study is made up off a total of 30 social studies teacher candidates (18 females and 12 males) studying at Social Studies Education Department of Niğde University's Faculty of Education during the 20142015 academic year.

As can be seen by the Table 1 , while $60 \%$ of participants are female, $40 \%$ of them are male.

As can be seen from Table 2, the ages of the participants range from 19 (1 participant) to 23 (5 participants).

As can be seen from Table 3 , while $70 \%$ of the participants are $2^{\text {nd }}$ year students, $30 \%$ of them are $3^{\text {rd }}$ year students.

As can be seen from Table 4, 50\% of the participants' income level is between 501 - 1000 TL. While one participant's income is between 2501 - 3000 TL, one participant's income is between 0 - 500 TL.

Table 1. Distribution of the study group based on sex.

\begin{tabular}{ccc}
\hline Sex & f & \% \\
\hline Female & 18 & 60 \\
Male & 12 & 40 \\
Total & 30 & 100 \\
\hline
\end{tabular}

Table 2. Distribution of the study group based on age.

\begin{tabular}{ccc}
\hline Age & f & \% \\
20 & 10 & 33 \\
21 & 9 & 30 \\
22 & 5 & 17 \\
23 & 5 & 17 \\
19 & 1 & 30 \\
& & \\
\end{tabular}


Table 3. Distribution of participants based on year level.

\begin{tabular}{ccc}
\hline Year Level & f & $\%$ \\
\hline 2nd & 21 & 70 \\
3rd & 9 & 30 \\
Total & 30 & 100 \\
\hline
\end{tabular}

Table 4. Distribution of the participants based on income level.

\begin{tabular}{ccc}
\hline Income Level & f & $\%$ \\
\hline $2501-3000$ & 1 & 3 \\
$2001-2500$ & 3 & 10 \\
$1501-2000$ & 4 & 13 \\
$1001-1500$ & 6 & 20 \\
$501-1000$ & 15 & 30 \\
$0-500$ & 1 & 3 \\
Total & 30 & 100 \\
\hline
\end{tabular}

As can be seen in Table 5, $3 \%$ of the participants stated that their father was illiterate. $+7 \%$ of their fathers have elementary school diploma. One of the participant's father has an education level university or higher.

As can be seen from Table 6, while 43\% of the participants' mothers have elementary school diplomas, 33\% of them were illiterate. There are 2 participants whose mothers have middle school diplomas and there are five participants whose mothers have high school diplomas.

\subsection{Data Collection Tool}

17-item scale with seven descriptive questions and 10 two-point Likert questions determining candidates' (Table 7) sensitivity was developed by the researcher after making use of several studies on historical cultural heritage (Aktın, Karakuş, \& Sağlam, 2013; Dinç, Erdil, \& Keçe, 2011; Alkış \& Oğuzoğlu, 2005; Kılcan \& Akbaba, 2013; Meydan \& Akkuş, 2014; Giménez, Ruiz, \& Listán, 2008; Metin, 2012). Also, 23-item survey with 13 three-point Likert questions measuring candidates' academic knowledge and the sensitivity scale was developed by the researcher after making use of several related works (Akgündüz, 1993; Öz, 1998; Öcal, 2012). The survey was administered to 30 Social Studies teacher candidates attending Niğde University's Education faculty. The teacher candidates were informed about the survey's purpose and pre-test and post-test. Candidates were informed again before they answered the survey after the lecture given in the classroom. Candidates were also informed again before the post-test given before and after field trip.

Tarsus was selected as the place where the teacher candidates would take their field trip to since Tarsus is one of the richest districts of Turkey in terms of historical cultural heritage. With its protected historical cultural sites, Tarsus has a long history with its unique architectural heritage works. The foundation date of tarsus dates back to the Phoenicians (Akgündüz, 1993). In later periods, The Assyrians, Cilicians, Persians, Macedonians, Seleucids, Romans and Byzantines ruled the city. With the weakening of Byzantines, Tarsus was raided by the Muslims. With the Muslim raids, the Umayyads, Abbasids, Seljuks and Mamluks began to rule the city. During the Mamluks, Turkish raids to Anatolia increased and many Turkish principalities formed. During the Ramazanoğulları Principality, traces of Turkish-Islamic culture began to be seen in Tarsus. Tarsus became a part of the Ottoman Empire after Sultan Selim's campaign to Egypt in 1517. It became a sanjak (Ottoman administrative unit) first tied to Cyprus Providence and later to Adana Province (Akgündüz, 1993). By the year 2012, there were a total of 215 registred monuments that were under protection. Some of the main ones are protected Roman Road, Saint Paul Well, Prophet Daniel Mosque, Makam Mosque, Kırkkaşık Bedesteni, Government House, Ulu Mosque, Saint Paul Church, Gözlükule Mound and Cleopatra Door. Many of the architectural structures that make up Tarsus's historical heritage are in Tarsus's central business area where the traditional trades and crafts still exist. This area has unique characteristics that reflect the traditional trades and crafts that have been continuing for a long time (Ünlü, 2009). The other structures are historical houses, several mosques and a bazaar (Öcal, 2012). 
Table 5. Distribution of the participants based on their fathers' education level.

\begin{tabular}{|c|c|c|}
\hline Fathers' Education Levels & $\mathbf{f}$ & $\%$ \\
\hline \multicolumn{3}{|l|}{ Illiterate } \\
\hline Elementary School & 1 & 3 \\
\hline Middle School & 14 & 47 \\
\hline High School & 8 & 27 \\
\hline University and & 6 & 20 \\
\hline Higher & 1 & 3 \\
\hline Total & 30 & 100 \\
\hline
\end{tabular}

Table 6. Distribution of the participants based on their mothers' education level.

\begin{tabular}{ccc}
\hline Mothers' Education Levels & f & $\%$ \\
\hline Illiterate & 10 & 33 \\
Elementary School & 13 & 43 \\
Middle School & 2 & 7 \\
High School & 5 & 17 \\
Total & 30 & 100 \\
\hline
\end{tabular}

Table 7. Likert questions.

1. I am generally interested in history and cultural works.

2. I enjoy learning about historical and cultural works and visiting.

3. I prepare and get information before I visit historical and cultural works.

4. I would like to examine and learn everything in detail during my visits to historical and cultural sites.

5. I have a general knowledge about works in Tarsus and the surrounding area.

6. I visited many of the historical and cultural works in Tarsus and surrounding area.

7. I haven’t visited historical and cultural works in Tarsus and the surrounding area because I didn’t have enough time.

8. I haven’t visited historical and cultural works in Tarsus and the surrounding area because I didn’t have enough money.

9. I haven’t visited historical and cultural works in Tarsus and the surrounding area because they don’t interest me.

10. Historical and cultural works in Tarsus and its surrounding areas are important for learning Tarsus's history and culture.

\subsection{Data Analysis}

The data obtained from the pre-test and post-test survey administered to Social Studies teacher candidates was analyzed by SPSS software package. Simple statistical analyses were done for each question. To determine whether there is a significant difference between Social Studies teacher candidates' sensitivity towards historical cultural heritage and their academic knowledge about the subject or not, dependent t-test was used for the measurements before and after the field trip.

\section{Finding and Comment}

Data related to the two sub-problems of the survey administered to Social Studies teacher candidates were analyzed. The findings obtained from the pre-test and post-test analysis are given below.

\subsection{Finding Related to the First Sub-Problem}

As can be seen from Table 8 , there is a 1.60 point difference between teacher candidates' sensitivity towards historical cultural heritage pre-test $(\bar{X}=23.90)$ and post-test $(\bar{X}=25.50)$ scores depending on the education method used. After the t-test, the difference was found statistically significant $\left(\mathrm{t}_{(29)}=-2.430 ; \mathrm{p}<0.05\right)$. Thus, based on these results, it can be said that the field trip taken effected significantly teacher candidates' sensitivity 
towards historical cultural heritage.

\subsection{Finding Related to the Second Sub-Problem}

As can be seen from Table 9, there is a 4,2 point difference between teacher candidates' academic knowledge about historical cultural heritage pre-test $(\bar{X}=7.76$ ) and post-test ( $\bar{X}=11.96$ ) scores depending on the education method used. After the t-test, the difference was found statistically significant $\left(\mathrm{t}_{(29)}=-14.324 ; \mathrm{p}<0.001\right)$. Thus, based on these results, it can be said that the field trip taken effected significantly teacher candidates' academic knowledge about historical cultural heritage.

\section{Result and Discussion}

The reason why Tarsus is chosen for field trip is because Tarsus has multicultural and very old heritages. There was a significant difference between the pre-test and post-test scores of teacher candidates' sensitivity towards Tarsus's historical cultural heritage sites and academic knowledge of these sites. It is seen that traditional lecture also affected candidates' academic knowledge and sensitivity. Candidates having information beforehand about the places they will visit have effect on the scores. Also, candidates being from a city close to Tarsus have effect on the scores.

Other studies about historical cultural heritage education, also, include field trips, especially to museums. The following is some of the benefits of taking field trips to the museums: Student learning will be more effective; certain concepts will become more concrete; students will be able to understand the link between the past and present; museums provide the opportunity for students to learn by doing; what students learn in museums will contribute most to the social studies objectives; museum field trips will increase students sensitivities towards historical cultural heritage. These findings are similar to Gökmen’s (2010) findings that showed teachers benefitting from museums $65 \%$ in life sciences lessons, 52\% in social studies lessons, $6 \%$ in Turkish lessons and 3\% in visual arts lessons. Teachers identified social studies lesson as the lesson in which they take their students to field trips to the most. Okvuran (2012) stated that drama activities in the museum facilitated education by making the concepts of past, present and future concrete for the students. In his "Cultural heritage in terms of values" category, metaphors developed by teacher candidates were divided into two sub-categories as national values and universal values. The metaphors under the national values sub-category were patriotism, family loyalty, love for Atatürk, loyalty and independence. The metaphors under the universal values sub-category were respected for differences, art, love, respect, right to live and tolerance. In a study conducted by Deveci (2009), social studies teacher candidates were asked to create cultural portfolios and these portfolios were analyzed by descriptive analysis technique. As a result of the analyses, elements used by teacher candidates to explain culture were identified. Among these elements, historical works, values, religious festivals and art are similar to this study

Table 8. Comparison of teacher candidates' sensitivity pre-test and post-test scores for dependent groups with t-test.

\begin{tabular}{|c|c|c|c|c|c|c|c|}
\hline & Measurement & & $\mathrm{N}$ & $\begin{array}{l}\text { Average } \\
\text { Standard } \\
\text { Deviation }\end{array}$ & sd & $\mathrm{t}$ & $\mathrm{p}$ \\
\hline Pre-test & 30 & 30 & 23.90 & 2.34 & 29 & -2.43 & $0.22^{*}$ \\
\hline Post-test & 30 & 30 & 25.50 & 3.11 & & & \\
\hline
\end{tabular}

${ }^{*} \mathrm{p}<0.05$.

Table 9. Comparison of teacher candidates' academic knowledge pre-test and post-test scores for dependent groups with t-test.

\begin{tabular}{|c|c|c|c|c|c|c|c|}
\hline & Measurement & & $\mathrm{N}$ & $\begin{array}{l}\text { Average } \\
\text { Standard } \\
\text { Deviation }\end{array}$ & sd & $\mathrm{t}$ & $\mathrm{p}$ \\
\hline Pre-test & 30 & 30 & 7.76 & 1.48 & 29 & -14.324 & $0.000^{*}$ \\
\hline Post-test & 30 & 30 & 11.96 & 0.81 & & & \\
\hline
\end{tabular}

${ }^{*} \mathrm{p}<0.001$. 
(Ay \& Fidan, 2013). As a result, it can be said that students develop positive attitudes towards cultural heritage through the in-class and out of the classroom activities and students participate in cultural heritage education (Dönmez \& Yeşilbursa, 2014). While these values and attitudes are developing, there were significant differences in sensitivities, too. There was a significant difference between the pre-test and post-test scores of teacher candidates' sensitivity towards historical cultural heritage sites due to the field trip taken. After the t-test, the difference was found statistically significant. Thus, based on these results, it can be said that the field trip taken effected significantly teacher candidates' sensitivity towards historical cultural heritage.

The reason behind students associating culture with social studies is because Turkish and history lessons may associate cultural subjects with past, language and human relations. Furthermore, it can be said that students' awareness is high in regards to culture being a concept created by people. Students associating the concept of culture with courses related to human sciences show their awareness. Therefore, increasing activities and applications related to cultural subjects in the aforementioned course contents can be beneficial (Ünlü, 2012). In his study titled "Examination of History Students' Interest and Awareness about Historical and Cultural Works", Metin (2010) expressed that history students were generally interested in historical and cultural works and enjoyed learning about historical and cultural sites and visiting them. It was found that male teacher candidates' knowledge and awareness levels were higher than the those of female ones. Positive attitudes of male teacher candidates towards historical and cultural works naturally reflected as a significant difference in their knowledge and awareness levels. In their study called "Examination of Uşak University Students' Interest and Awareness about Historical and Cultural Works”, Dinç, Erdil, \& Keçe (2011) state that teacher candidates' attitudes, interest and awareness levels were above average without any significant difference among females and males (Aktın et al., 2013). When the measurement results of social studies teacher candidates' academic knowledge about historical cultural heritage were taken into consideration, there was a significant difference between the pre-test and post-test scores due to the field trip taken. After the t-test, the difference was found statistically significant. Thus, based on these results, it can be said that the field trip taken effected significantly teacher candidates' academic knowledge about historical cultural heritage.

\section{Suggestions}

In the study, the positive attitudes the social studies teachers had affected their sensitivity and academic knowledge. Therefore, to develop positive sensitivities in social studies the following are recommended.

Historical cultural heritage course that is taught as an elective course in the Departments of Social Studies Education of education faculties should be taught as a compulsory course because when the course is elective, many students do not learn about the subject. Furthermore, compared to students who take this course, the ones who do not take this course do not have the same academic knowledge and do not show as much sensitivity as the others. Moreover, in our country's school curriculum historical cultural heritage is given and students are informed.

In addition to making historical cultural heritage courses compulsory, the students should have field trips to historical cultural heritage sites. Especially local historical cultural sites should be identified and the courses should be planned around field trips to these sites. The number of field trips that the teacher candidates take should be increased because the candidates who take practical courses are able to teach better and prepare more sensitive future generations when they become teachers.

In Social Studies Departments, the historical cultural heritage sites of the city that the university is in should be identified and field trips should be organized. In middle school social studies curriculum the subjects taught go from the local to the national. So, the local historical cultural heritage sites are important. Thus, the number of field tips should be increased so that the students learn more about the local historical cultural heritage.

\section{References}

Akgündüz, A. (1993). Tarsus History and Eshab-I Keyf in the Light of Archives. Tarsus: Tarsus Ticaret ve Sanayi Odas1, Cihan Neşriyat ve Matbaacılık.

Aktın, K., Karakuş, H., \& Sağlam, H. (2013). Interest and Awareness Levels of the Teacher Candidates from Sinop University about the Historical and Cultural Monuments in Sinop. International Journal of Social Science, 6, 37-59. http://dx.doi.org/10.9761/JASSS1860

Alım, M. (2009). A Cultural Geography Study: Navruz In Igdır, Doğu Coğrafya Dergisi, 14, 231-238. 
Aliağaoğlu, A. (2004). Social-Cultural Heritage Tourism and Examples from Turkey. Ankara Üniversitesi Türkiye Coğrafya Araştırmaları Merkezi coğrafi Bilimler Dergisi, 2, 55-70.

Alkış, S., \& Oğuzoğlu, Y. (2005). Importance of Historical Environmental Education in Our Country and Factors Affecting Its Necessity. Eğitim Fakültesi Dergisi, XVIII, 347-361.

Arslanoğlu, İ. (2001). Concepts of Culture and Civilization. Hacı Bektaş Veli Araştırma Dergisi, 15, 243-255.

Atasoy, S. (1978). Museums as Education Institutions. Arkeoloji ve Sanat, 1, 20-22.

Ay, T. S., \& Fidan, N. K. (2013). Teacher Candidates’ Metaphors Related to the Concept of “Cultural Heritage”. Turkish Studies-International Periodical for The Languages, Literature And History of Turkish or Turkic, 8, 1135-1152.

Corbishley, M. (2000). Living Heritage. History Today, 50, 36, 2p, 2c (Ebsco).

Doğaner, S. (2003). Geographical Recourses and Preservation of Heritage Tourism. Coğrafi Çevre Koruma Turizm Sempozyumu, Bildiri Kitab1, Ege Üniversitesi Edebiyat Fakültesi Yayını, İzmir, 16-18 Nisan 2003, 1-8.

Dönmez, C., \& Yeşilbursa, C. C. (2014). The Effect of Cultural Heritage Education on Students’ Attitudes toward Tangible Heritage. Elementary Education Online, 13, 425-442. http://ilkogretim-online.org.tr

Emekli, G. (2006). Geography, Culture and Tourism: Cultural Tourism. Ege Coğrafya Dergisi, 15, 51-59.

Emekli, G. (2005). The Policies of the Tourısm in European Union and Cultural Tourism in Turkiye. Ege Coğrafya Dergisi, 14, 99-107.

Giménez, J. E., Ruiz, R. M. Á., \& Listán, M. F. (2008). Primary and Secondary Teachers’ Conceptions about Heritage and Heritage Education: A Comparative Analysis. Teaching and Teacher Education, 24, 2095-2107. http://www.sciencedirect.com/science/journal/0742051X/24 http://dx.doi.org/10.1016/j.tate.2008.02.017

Gökmen, H. (2010). Architecture and Children Works: Structural Environmental Education. Mimarlık, 352. http://www.mimarlikdergisi.com/

Gülcan, B. (2010). Body of Cultural Tourism in Turkey and Need of Product Differentiation Based on Tangible Cultural Assets. Işsletme Araştırma Dergisi, 2, 99-120.

Güleç, S., \& Alkış, S. (2003). Communicational Dimension of Museum Field Trips in Social Studies Education. Uludağ Üniversitesi Ĕ̌itim Fakültesi Dergisi Cilt, 17, 63-78.

Güvenç, B. (1994). Human and Culture. İstanbul: Remzi Kitapevi, 48.

Hooper-Greenhill, E. (1994). Museum Education: Past, Present and Future. In R. Milles, \& L. Zavala (Eds), Towards the Museum of the Future (pp. 133-146). London and New York: Routledge.

Işık, H. (2008). The Effects of Combination of the History Subjects with Local History on the Success of Students in Primary School. Uluslararası Sosyal Araştırmalar Dergisi, 1/4, 290-310.

Karasar, N. (2005). Scientific Research Method, 15. Ankara: Baskı. Nobel Yayın Dağıtım.

Kilcan, B., \& Akbaba, B. (2013). Examining Students’ Perceptions on Sensitivity to Cultural Heritage Value in Social Sciences Teaching Program. Zeitschrift für die Welt der Türken, 5, 113-138.

Mercin, L. (2002). Evaluation of Art School Teachers' and Administrators’ Perception Related to Using Museums for Art Education. Ankara: Yüksek Lisans Tezi.

Metin, E. (2012). Examination of History Students’ Interest and Awareness about Historical and Cultural Works. http://www.cansaati.org/topluluk/forum posts.asp?TID=3770\&title=tarih-blmrencilerine-gre-ankiri

Meydan, A., \& Akkuş, A. (2014). The Importance of Getting Students Adopt the Historical and Cultural Values through Museum Visits in Social Studies Teaching. Marmara Coğrafya Dergisi, 29, 402-422.

Ott, M., \& Pozzi, F. (2011). Towards a New Era for Cultural Heritage Education: Discussing the Role of ICT. Computers in Human Behavior, 27, 1365-1371. www.elsevier.com/locate/comphumbeh http://dx.doi.org/10.1016/j.chb.2010.07.031

Ott, M., \& Pozzi, F. (2008). ICT and Cultural Heritage Education: Which Added Value? In M. D. Lytras et al. (Eds.), WSKS, LNAI 5288 (pp. 131-138). Berlin Heidelberg: Spiringer-Verlag.

Öcal, T. (2012). Tourism Planning of Historic-Cultural Heritage Regions in Tarsus City. Ankara Üniversitesi Dil Tarih ve Coğrafya Fakültesi coğrafya Bölümü, TÜCAUM VII, Coğrafya Sempozyumu Bildirisi, 18-19 Ekim 2012, 335-346.

Öz, H. (1998). Unknown Tarsus, Türkiye Cumhuriyeti Kültür Bakanlığı Tanıtma Eserleri, 2038, Kitaplar Dizisi 75. Ankara: Türk Tarih Kurumu.

San, İ. (1998). Müze Eğitim Bilimi Nasıl Gelişti? Milliyet Sanat, 444.

Sternberg, S. (1989). The Art of Participation. In N. Berry, \& S. Mayer (Eds.), Museum Education History, Theory and Practice (pp. 257). Reston, VA: The National Art Education Association Editors. 
Şahan, M. (2005). Museums and Education. Türk Eğitim Bilimleri Dergisi, 3, 487-501. http://www.tebd.gazi.edu.tr/arsiv/2005_cilt3/sayi_4/487-501.pdf

Taş, A. M., \& Yıldız, N. (2015). Metaphors about the Concept of "Museum” of 4th Graders in One Elementary School in Turkey. International Journal of Education, 7, 19-30.

Timothy, D. J., \& Boyd, S. W. (2003). Heritage Tourism. Harlow: Prentice Hall.

Tören, E., Kozak, N., \& Demiral, G. N. (2003). Public Institutions’ Role in Preservation of Cultural Heritage Works in Eskişehir. Aksaray Üniversitesi İktisadi İdari Bilimler Fakültesi Dergisi, 2, 69-88.

Restructuring of History Education in Turkish Elementary and Secondary Schools, Atölye 1, 2-3 (2000). Orta Doğu Teknik Üniversitesi Kongre ve Kültür Merkezi, Ankara, Türkiye Ekonomik ve Toplumsal Tarih Vakfi, İstanbul: Reyo Matbaas1.

UNESCO (1972). Convention concerning the Protection of the World Cultural and Natural Heritage. 14.02.1983 tarih ve 17959 sayılı Resmi Gazete.

Uygur, S. M., \& Baykan, E. (2007). Culture Tourism and Effect of Cultural Tourism and Tourism on Cultural Wealth. Ticaret ve Turizm Eğitim Fakültesi Dergisi, 2, 30-48.

Ünlü, İ. (2012). The Examination of the Culture Perception of the Elementary 8th Grade Students. Ahi Evran Üniversitesi Kırşehir Ĕgitim Fakültesi Dergisi (KEFAD), 13, 77-92.

Ünlü, T. (2009). Designing Urban Transformation Process: Tarsus Historical Commercial Center, 32. Dünya Şehircilik Günü Kolokyumu “nda Sunulan” Kentte Dönüşümün Bir Süreç Olarak Tasarlanmas1, Mimar Sinan Üniversitesi, 3-4, 145-157. http://www.unesco.org.tr/dokumanlar/somutkulturelmiras/somut_kulturel_miras.pdf 